\title{
O Partido Comunista do Brasil e a crise do socialismo real
} The Communist Party of Brazil and the crisis of real socialism

Jean Rodrigues Sales*

\section{Resumo}

$\mathrm{O}$ artigo analisa o impacto da crise do socialismo real na trajetória do Partido Comunista do Brasil. Destaca os caminhos escolhidos pelo partido para lidar com os dilemas do fim do socialismo no Leste Europeu e as modificações pelas quais passaram as suas formulações políticas na década de 1990, em conseqüência das transformações do comunismo em nível mundial.

Palavras-chave: Partido Comunista do Brasil; crise do socialismo real; política.

\begin{abstract}
This article analyzes the impact of the crisis of real socialism on the trajectory of the Communist Party of Brazil. It highlights the courses chosen by the party to deal with the dilemmas that resulted from the end of socialism in Eastern Europe, as well as the changes in the party's political formulations of the 1990's which resulted from the transformations in communism at the world level.
\end{abstract}

Keywords: Communist Party of Brazil; crisis of real socialism; politics.

Fundado no início da década de 1960, a partir de uma cisão no Partido Comunista Brasileiro (PCB), o Partido Comunista do Brasil (PCdoB) conta hoje com 46 anos de atividade política. Durante esse trajeto, a agremiação passou por muitos percalços: sobreviveu ao período da ditadura militar, à disputa ideológica com sua matriz, o PCB, à guerrilha do Araguaia, à concorrência de novas forças de esquerda surgidas no início dos anos 80, em particular do Partido dos Trabalhadores (PT), e, principalmente, à crise do socialismo real, que enfraqueceu a maioria dos partidos comunistas existentes no mundo.

O PCdoB não apenas sobreviveu como ampliou a sua inserção política nas décadas de 1980 e 1990. Conseguiu espaço no movimento sindical e estudantil e tem elegido vereadores, deputados e, mais recentemente, prefeitos e senadores. Além disso, em 2002, participou da coalizão que elegeu o presi-

\footnotetext{
* Centro de Ciências Humanas, Letras e Artes, Universidade Estadual do Centro-Oeste (Unicentro). Rua Presidente Zacarias, s/n - Santa Cruz. 85015-430 Guarapuava - PR - Brasil. jeanrodrigues5@yahoo.com.br.
} 
dente Luís Inácio Lula da Silva. No primeiro mandato de Lula, um de seus dirigentes, Aldo Rebelo, ocupou a presidência da Câmara dos Deputados, o que representa exemplo único no país de um comunista a ocupar tal cargo.

Considerando essa trajetória, o partido foi relativamente pouco estudado e continua a merecer mais pesquisas acadêmicas a seu respeito. Na produção sobre a agremiação, os temas tratados dizem respeito principalmente à década de 1960 e à primeira metade dos anos 70, o que corresponde ao período de seu surgimento, estruturação orgânica e envolvimento na guerrilha do Araguaia. Além disso, grande parte dos livros a seu respeito é fruto de trabalhos jornalísticos, de documentos do próprio partido ou de ex-militantes. ${ }^{1}$

Este artigo pretende contribuir para o entendimento da história recente ${ }^{2}$ do PCdoB ao tratar da forma como ele lidou com a crise que se abateu sobre o socialismo real nas décadas de 1980 e 1990. Buscar-se-á compreender como esse partido, diferentemente de seus congêneres no Brasil e por todo o mundo ocidental, logrou superar as dificuldades e ampliar a sua força política. Antes, porém, faz-se necessário traçar um breve histórico da trajetória da agremiação, desde o final dos anos 70, para que se possa medir com acuidade as transformações operadas em seu interior, no momento em que sobre ele se abateu a crise internacional do comunismo.

\section{A abertura política e a Nova República}

As propostas aprovadas pelo PCdoB em sua VII Conferência, realizada na Albânia, em 1979, podem ser apontadas como o momento inicial da política que seria adotada pelo partido na abertura democrática em curso no país: abolição total e imediata de todos os atos e leis arbitrárias, anistia geral e irrestrita e convocação, por um governo provisório e democrático, de uma constituinte livremente eleita. Para se colocar em prática tal orientação, era necessária a mais ampla união de forças políticas contrárias à ditadura. Nesse caminho, e de acordo com as proposições de seu VI Congresso, realizado em 1983, o grupo optou pelo engajamento no Movimento Democrático Brasileiro $(\mathrm{MDB})$ e pelo apoio ao Colégio Eleitoral, à Nova República e ao governo Sarney, na tentativa de garantir a governabilidade para evitar os riscos de retrocesso político, ameaça que estaria presente nas articulações de setores das Forças Armadas.

Ao mesmo tempo em que praticava uma política bastante moderada em sua proposta de abertura política, o PCdoB, no início da década de 1980, se mostrava contrário às forças que tinham um projeto mais crítico à Nova República, sobretudo o Partido dos Trabalhadores (PT) e a Central Única dos 
Trabalhadores (CUT), então em processo de fundação. Sobre o primeiro, o PCdoB afirmava que não passava de um partido falsamente proletário que seria, na realidade, um agrupamento tipicamente social-democrata. A respeito da CUT, a crítica era motivada por ela fazer parte do projeto petista, contraposto à política de frente ampla assumida pelo $\mathrm{PCdoB}$.

Enquanto criticava outras forças de oposição, o PCdoB investia em sua atuação no setor sindical da região do São Bernardo do Campo, em São Paulo, onde aconteciam greves que aos poucos colocavam os militares em alerta. A partir dessas mobilizações, o partido conseguiu eleger, em 1978, na legenda do MDB, o seu primeiro deputado federal, o operário Aurélio Peres. Na eleição de 1976, o partido já conseguira eleger alguns vereadores nas capitais, como Benedito Cintra, em São Paulo. Em 1982, o partido elegeu o prefeito de Camaçari, na Bahia, pela legenda do Partido do Movimento Democrático Brasileiro (PMDB). Durante esse período, de 1976 a 1984, chegou ainda a ocupar alguns cargos de baixo escalão em governos e prefeituras do MDB e do PMDB. Foi, porém, após a legalização do partido, em 23 de maio de 1985, que ele passou a atuar regularmente nos pleitos eleitorais. $\mathrm{Na}$ eleição para a Assembléia Constituinte de 1986, por exemplo, elegeu cinco deputados no Rio de Janeiro, na Bahia, em Goiás e Alagoas, além de vários deputados estaduais.

Na segunda metade dos anos 80, o partido reorientaria a sua atuação. No início de 1987, abandonou o apoio crítico ao governo Sarney, passando à oposição. No ano seguinte, realizou o seu VII Congresso, no qual reafirmou o seu deslocamento à esquerda na cena política nacional, o que se traduziu na palavra de ordem Fora Sarney, Diretas 88! No mesmo caminho, redefiniu a sua política de alianças no plano interno. Ainda que continuasse criticando alguns aspectos da proposta política do PT, passou a fazer alianças com esse partido, ao mesmo tempo em que, no plano sindical, se aproximou da CUT. Nesse caminho, ainda em 1988, PT e PCdoB participaram de coligações que elegeram prefeitos de cidades importantes do país, como Santos e a capital paulista. No ano seguinte, integraram a Frente Brasil Popular, que deu sustentação à primeira candidatura de Luís Inácio Lula da Silva a presidente.

\section{O VII Congresso e os ecos da Perestroika}

Em maio de 1988, o PCdoB realizou o seu VII Congresso. O evento não foi marcado por grandes polêmicas entre os participantes. Analisando a "Tribuna de Debates" (encarte do jornal oficial do partido, A classe operária, para as discussões que antecederam o congresso), percebe-se que a maior parte dos 
artigos publicados ressalta a importância do PCdoB para a vida política nacional ou aponta a necessidade de se melhorar o funcionamento partidário em setores como os de propaganda, finanças, organização, sindical, camponês etc. A ausência de discussões mais profundas fica evidente, se considerarmos a exigüidade de tempo para discussão pública, uma vez que cada militante podia publicar apenas um artigo, com direito a uma resposta, caso fosse contestado. Além disso, apenas cinco números da Tribuna de Debates foram publicados entre março e maio de 1988. Se pensarmos que esse foi o primeiro congresso do partido realizado legalmente, é possível questionar os motivos do pouco tempo dedicado aos debates, e a resposta passa certamente pela persistência de práticas pouco democráticas que marcam o funcionamento dos partidos comunistas.

Além dos temas nacionais, como a aproximação ao PT e à CUT e a oposição ao governo Sarney, as discussões sobre a situação internacional, particularmente a respeito da crise do socialismo real, estiveram presentes no conclave. É certo que sempre foi uma característica comum aos partidos comunistas o debate sobre os caminhos do movimento comunista internacional, e o $\mathrm{PCdoB}$, durante toda a sua trajetória, esteve atento a tal problemática. O momento, em 1988, era, contudo, delicado para os países comunistas e pedia ainda mais atenção. O socialismo real estava em crise, muitos países o abandonaram e adotaram o regime capitalista. Para agravar a situação, a própria União Soviética, apontada pelos comunistas como a pátria do socialismo, vivia os processos da Perestroika e da Glasnost, liderados por Mikhail Gorbachev e precursores do fim do regime socialista naquele país. Além disso, no mundo todo, os partidos comunistas entraram em crise. Alguns mudaram de nome, outros se reduziram a pequenos agrupamentos sem nenhuma importância política. ${ }^{3}$

O PCdoB, no entanto, não se considerava particularmente ameaçado pela crise que tomava conta do mundo comunista. Ao contrário, afirmava, por contraditório que possa parecer, que os eventos que se sucediam na Europa demonstravam o acerto da análise que fazia desde 1963. Por essa ótica, as reformas em curso não passariam de uma "nova versão e nova ofensiva do revisionismo soviético contra o movimento revolucionário", "revisionismo" criticado pelo PCdoB desde a década de 1960. A principal diferença entre os períodos de Khrutchev e Gorbachev, de acordo com o partido, era a transformação do "revisionismo envergonhado, que procurava passar o contrabando burguês disfarçadamente, a revisionismo sem máscara, que adere abertamente ao capitalismo - eis a trajetória dos renegados soviéticos agora adeptos da PERESTROIKA". ${ }^{4}$ 
Diante da crise que se abatia sobre o mundo comunista, a esperança do partido se ancorava na experiência da pequena Albânia, onde haveria, segundo o PCdoB, uma forte resistência "à pressão imperialista-revisionista", e os trabalhadores, juntamente com o Partido do Trabalho da Albânia (PTA), "dirigem com êxito a construção da nova vida de progresso, cultura, liberdade e justiça social. Toda a sua atividade fecunda guia-se pela lei econômica fundamental do socialismo...". Assim, uma das tarefas do PCdoB era defender a Albânia socialista, que mantinha vivas as idéias de "Marx, Engels, Lênin e Stalin" (PCdoB, 1989, p.15).

\section{A CRISE DO SOCIALISMO REAL E O VIII CONGRESSO}

Com a crítica feita ao "novo revisionismo", o PCdoB imaginara-se livre dos problemas suscitados pelo fim do socialismo real. Entretanto, a crise dos países do Leste Europeu e, particularmente, as mudanças ocorridas na Albânia, até então apontada como bastião do comunismo mundial, levaram o partido a modificar a sua análise. Com efeito, até 1990 era comum o caso albanês aparecer nas declarações partidárias, "em meio à tempestade anticomunista", como exemplo de que o socialismo não era "um sistema social morto", mas sim o responsável pelo desenvolvimento econômico, político e cultural pelo qual passava a Albânia. Assim, o fim do regime socialista nesse pequeno país abalou os últimos pilares da ortodoxia em que o PCdoB se apoiava e o fez convocar o seu VIII Congresso para 1992, o qual, estatutariamente, deveria ocorrer apenas em 1993. ${ }^{5}$

Esse foi o congresso mais importante da história do PCdoB. O alcance de suas resoluções marcou profundamente a sua identidade política e ideológica. Entre outros aspectos, cabe destacar a crítica feita ao stalinismo, mesmo que permeada de nuanças, o abandono da teoria da revolução por etapas, o realinhamento de sua política internacional e a afirmação da necessidade de procedimentos democráticos na estrutura partidária.

Outra característica marcante do congresso foi o fato de pela primeira e, possivelmente, única vez na história partidária, o debate preparatório ter transcorrido com um grau maior de liberdade de expressão, o que não impediu, entretanto, que militantes tenham denunciado tentativas de limitação das críticas que se avolumavam ao funcionamento do partido. De qualquer maneira, a comparação com o conclave anterior demonstra a preocupação em ampliar o debate interno. Enquanto no VII Congresso cada militante poderia apresentar um artigo, com direito a uma resposta, nas cinco edições da Tribuna, no congresso seguinte podiam-se publicar quatro textos e foram publica- 
das dez edições da Tribuna de Debates. No mesmo caminho, o número total de contribuições aumentou de 191 para 395 entre os dois congressos em discussão.

O Comitê Central apresentou três teses para nortear o debate: "A luta pelo socialismo científico", "Problemas atuais do Brasil e do mundo" e "Questões de organização do partido". A primeira foi a que gerou maior discussão no transcorrer do congresso. A origem da crise do socialismo, como o PCdoB já havia afirmado em outros momentos, foi atribuída à chegada ao poder da corrente "revisionista" liderada por Khrutchev. A diferença da análise reside no apontamento dos erros cometidos durante o período de "construção do socialismo", o que significava dizer, no período de permanência de Josef Stalin no poder. É importante frisar que não há uma crítica clara a Stalin. Ao contrário, o dirigente soviético é descrito como alguém que cometera "sérios equívocos", mas que personificara "as idéias comunistas" de Marx, Engels e Lênin. A única restrição feita a Stalin diz respeito ao caso Lyssenko, ${ }^{6}$ que, com o aval do dirigente soviético, teria obstaculizado o desenvolvimento científico na União Soviética.

É importante considerar que o PCdoB, desde o seu surgimento, era um defensor incondicional da figura de Josef Stalin. Uma das questões envolvidas na cisão que deu origem ao partido fora, inclusive, a aceitação, durante a realização do XX Congresso do PCUS, em 1956, das críticas endereçadas a Stalin. Naquele momento, o PCdoB marcou posição na defesa do stalinismo e passou a qualificar todos aqueles que o criticavam como expressões do revisionismo contemporâneo. O partido ficou marcado no panorama das esquerdas pela defesa intransigente do dirigente soviético. Paradoxalmente, tal como ocorrera em 1956 e 1962, assiste-se, no VIII Congresso, a um debate no qual Stalin aparece em destaque.

Mesmo sem referência direta ao nome de Stalin, as críticas feitas aos equívocos cometidos durante o período de construção do socialismo não podiam deixar de ser a ele endereçadas, uma vez que exerceu um poder quase absoluto enquanto esteve à frente da União Soviética. Entre os problemas apontados nas teses estava o da estagnação da teoria diante das grandes transformações sociais e na incorreta aplicação do marxismo-leninismo na condução do Estado socialista, sobretudo no que diz respeito às diferenças de idéias. Tais erros teriam se exprimido em "repressões continuadas e injustificáveis verificadas em diferentes períodos" e que teriam atingido "pessoas, culpadas ou não”. Para a direção do PCdoB, repressões desse tipo 
ferem o cerne do socialismo que se expressa numa ampla e livre participação de grandes massas em todas as tarefas vitais do sistema instituído. Geram o medo coletivo, sobretudo o temor de criticar os dirigentes. Transformam em apatia o ânimo revolucionário. Favorecem a irradiação do burocratismo. Os funcionários graduados do aparelho do Partido e do Estado tornam-se intocáveis, desfrutam privilégios, tendem à arrogância. Em tais condições, o partido de vanguarda separa-se das massas. A confiança dos trabalhadores e do povo no socialismo perde substância. ${ }^{7}$

Com a admissão de que esses erros foram cometidos durante o período em que Stalin esteve no poder, eclodiu um debate cujas fortes discussões demonstram que certas idéias estavam sufocadas pelo peso da estrutura partidária. Até a realização do VIII Congresso, qualquer crítica a Stalin seria certamente punida com a expulsão imediata do militante. Chegara, contudo, o momento em que muitos membros do PCdoB expressaram suas opiniões sobre Stalin, a União Soviética, o funcionamento do partido e os próprios dirigentes partidários.

Após a abertura dos debates, logo se verificou que o tema de maior destaque seria o da responsabilidade de Stalin nos erros cometidos na União Soviética e na crise pela qual passava o socialismo nas décadas de 1980 e 1990. Nesse ponto, as opiniões se dividem e podemos identificar pelo menos três tendências gerais nas contribuições. Vale ressalvar que tais tendências de idéias podem ser identificadas no conjunto das contribuições dos militantes, mas não indicam que houvesse correntes internas organizadas, o que era e continua sendo proibido pelas normas do PCdoB. Uma parte dos militantes apontava que a atuação de Stalin deveria ser analisada dentro das condições históricas em que ocorreu, considerando as dificuldades que enfrentou para assegurar a existência do socialismo na União Soviética. Um segundo conjunto de militantes afirmava que Stalin deveria ser responsabilizado claramente pelos desvios ocorridos na construção do socialismo. Por fim, uma terceira tendência fazia a defesa do legado de Josef Stalin e afirmava que criticá-lo significava fazer coro aos liberais e anticomunistas em geral.

No final do congresso, prevaleceu a primeira corrente. Entretanto, chama a atenção a crítica aberta feita a Stalin, nunca antes questionado pelo partido. Um dos participantes afirmava que foi necessária a avalanche do Leste Europeu para que se concluísse que Stalin também cometera erros. Entretanto, os erros cometidos pelo dirigente soviético não foram inconseqüentes: "foram erros que propiciaram a ascensão do revisionismo até culminar com o que vemos hoje". Em outra intervenção, uma participante lembrou fatos graves que nunca tinham sido considerados dentro do PCdoB. Para ela, ainda 
que a problemática da democracia não pudesse ser discutida fora de uma perspectiva classista, não existia argumento possível para justificar que dos 1.966 delegados do $17^{\circ}$ Congresso do PCUS, em 1934, 1.108 tenham sido presos, e a maior parte executada entre 1936 e $1938 .{ }^{8}$

Além das críticas diretas feitas a Stalin, apareceram discussões a respeito do funcionamento do próprio PCdoB, que teria cometido muitos erros, uma vez que era oriundo da mesma tradição do partido russo. Nesse caminho, um dos militantes afirmou que se não se perceberam antes os erros de Stalin, foi porque o stalinismo estava "dentro de nós" e "reproduzíamos a maior parte das atitudes ideológicas do PCUS”. Essa reprodução da postura por parte do PCdoB ocorrera quando o partido acalentava uma visão messiânica sobre si, apresentando-se como a vanguarda esclarecida que levaria o povo a uma revolução socialista inevitável; quando era pouco tolerante à divergência, desenvolvendo uma hierarquia rígida e limites à autonomia intelectual. No mesmo caminho, a prática stalinista que vigia no partido poderia ser verificada em orientações, tais como

impedir a publicação na Classe operária de um artigo que além de condenar duramente Gorbatchev e sua política, também criticava os burocratas golpistas. Encaminhar de forma autoritária e arrogante uma política que, mais tarde, foi comprovada pela vida, como se fez no $7^{\circ}$ Congresso. Impor aos Comitês Regionais candidatos, coligações e os próprios dirigentes regionais. Tratar qualquer companheiro que saia do partido como inimigo de classe ... Colocar na geladeira camaradas que assumem uma postura acentuadamente crítica em relação a erros do partido e posições da direção central, taxando-os de estar em crise ideológica ... Mudar repentinamente de posição sem a necessária e clara autocrítica, como fizemos, por exemplo, em relação à China e a Mao Tsé-tung, que, de genial intérprete criador do marxismo-leninismo, passou a jamais ter sido marxista. Acreditar na infalibilidade da direção e, particularmente, no camarada Amazonas. Tentar restringir ou intimidar o debate que agora se trava, acusando os camaradas que ousam polemizar de estarem inoculados pelo vírus do revisionismo e da social-democracia. Esses são alguns exemplos concretos do stalinismo que ainda cultivamos e cultuamos. ${ }^{9}$

Mais um tema que ganhou destaque, relacionado também aos problemas do funcionamento partidário, foi a avaliação feita pela direção a respeito das mudanças ocorridas na Albânia. O questionamento feito por parte da militância diz respeito à repentina e superficial análise do caso albanês e de suas implicações para o PCdoB. Um participante da Tribuna de Debates lembra que havia dois argumentos correntes para a explicação da crise albanesa. $\mathrm{O}$ 
primeiro seria a dificuldade objetiva de construção do socialismo em um único, pequeno e atrasado país. O segundo se referia ao acúmulo de erros dos dirigentes do Partido do Trabalho da Albânia na construção do socialismo. Segundo o militante, o problema estaria relacionado ao fato de o PCdoB nunca ter feito críticas à construção do socialismo albanês. Nesse sentido, "as virtudes e as deformações do socialismo albanês estão presentes na nossa concepção de socialismo". No mesmo caminho, um segundo participante questionava a mudança de postura sobre a Albânia sem discussões mais aprofundadas, o que se repetiria na reaproximação com a China e com Cuba, processo que também prescindiu de um debate teórico adequado. Por fim, mais um membro do partido argumentava que, tendo a crise da Albânia vindo de longa data, não poderia ela ser atribuída apenas a um líder. Assim, em suas palavras, "o nosso principal problema em relação à Albânia foi a expectativa que se criou em torno de sua infalibilidade" ${ }^{10}$

$\mathrm{Na}$ resolução do congresso podemos perceber algumas mudanças em relação às teses apresentadas pelo Comitê Central para discussão. Pode-se destacar um maior esclarecimento sobre a responsabilização do PCUS pelos problemas vividos na União Soviética e, particularmente, de Stalin na condução da construção do socialismo. Ainda que tenha vindo com todas as ressalvas sobre os aspectos positivos da atuação do comandante soviético, a resolução admitia, pela primeira vez na história do $\mathrm{PCdoB}$, que Stalin, como principal dirigente do PCUS e teórico marxista-leninista, tinha responsabilidade no desastre sucedido com o socialismo na URSS.

Entre os erros cometidos por Stalin, estavam a permissão ao culto de sua personalidade e a condução à subestimação do partido como organização de vanguarda, criando o "fetiche da direção que tudo sabe e tudo resolve, direção que se reduzia ao Birô Político e, dentro do Birô, a ele próprio”. Além disso, foi criticada a sua política de repressões continuadas e "possivelmente desnecessárias, com repercussão negativa na credibilidade do regime". No terreno da luta das idéias, o erro dizia respeito ao trabalho de acentuar o aspecto repressivo, dando menor importância ao outro fator, "o essencial, que é o da argumentação, o da fundamentação política e teórica”. Assim, apesar de suas contribuições "valiosas" no campo teórico, Stalin não esteve à altura da generalização da prática revolucionária, o que foi demonstrado no "subjetivismo, no empirismo, que se manifestaram na orientação do Partido". ${ }^{11}$

A nuança na conclusão a respeito da avaliação de Stalin mostra que, a despeito das críticas feitas ao dirigente soviético, havia dificuldade em aceitar o fato de o partido o ter apontado como responsável por erros cometidos no período de construção do socialismo na União Soviética. A saída encontrada 
foi a afirmação de que tais erros deveriam ser avaliados historicamente. Assim, não se negam os equívocos, mas se deixa um espaço para o entendimento do legado do dirigente soviético. Nesse caminho, o PCdoB afirma que não era stalinista, nem tampouco anti-stalinista, e que Stalin esteve, juntamente com o Partido Bolchevique, "à frente das grandes batalhas pela transformação radical do velho mundo capitalista. Nesses embates, a par dos méritos incontestáveis, mostrou falhas e deficiências, cometeu erros que prejudicaram a causa do proletariado" (PCdoB, 1992, p.46-49).

Na problemática da defesa do legado histórico de Stalin, há um detalhe revelador do papel que o dirigente soviético ocuparia a partir desse momento no seio do partido. Na Tribuna de Debates, alguns militantes já questionavam se as críticas feitas a Stalin significariam que a tradicional foto do dirigente soviético não apareceria ao lado de Marx, Engels e Lênin durante o encontro, como acontecera em todos os congressos anteriores. Um deles chegou a afirmar que, caso a foto não fosse colocada na mesa de trabalho, ele retiraria a sua filiação do PCdoB. Não sabemos se ele deixou o partido, mas a foto de Stalin não figurou no VIII Congresso, nem figuraria nos encontros seguintes. ${ }^{12}$

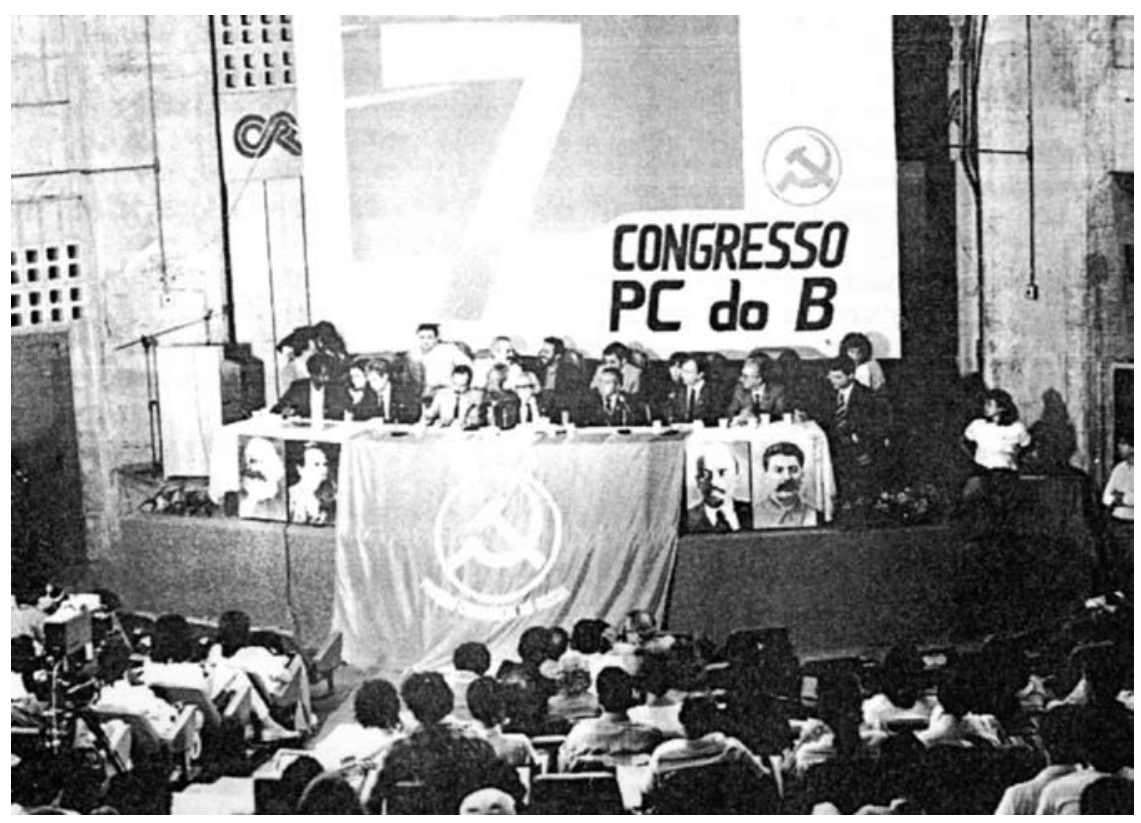

Figura 1 - No VII Congresso do PCdoB, realizado em 1988, aparecem logo abaixo da mesa de trabalho as fotos de Marx e Engels (à esquerda) e Lênin e Stalin (à direita). Esse foi a último evento do partido em que apareceria a imagem de Stalin. (fonte: Princípios. São Paulo: Anita Garibaldi, n.18, 1990. p.29). 

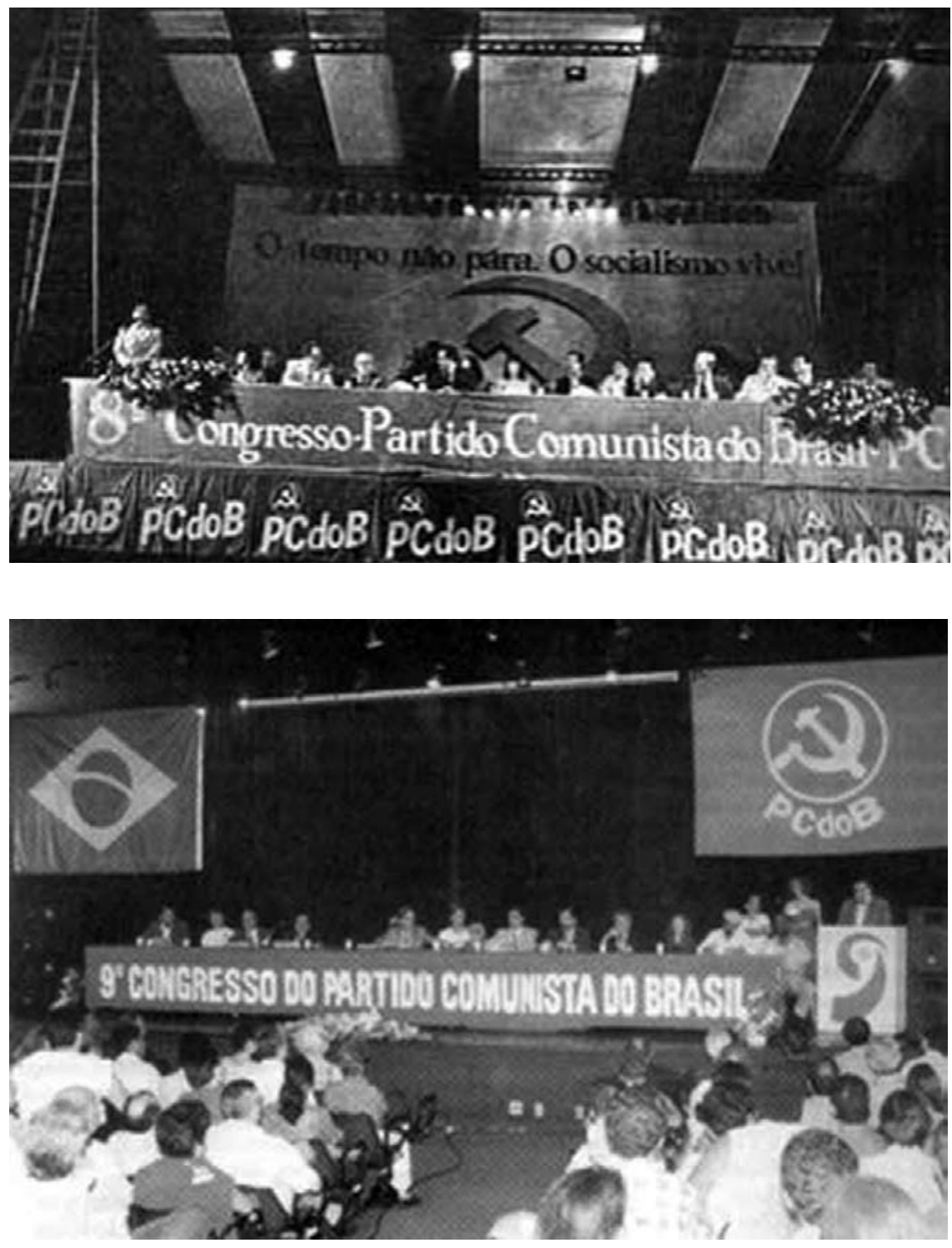

Figuras 2 e 3 - Imagens do VIII e IX Congressos do PCdoB. Realizados após a crise do socialismo real, não tiveram destaque as tradicionais fotos dos dignitários do socialismo. (fonte: Carlos Pompe. Congressos Comunistas. Na legalidade, luta para avançar a democracia. Diário vermelho, 6 out. 2005. Disponível em: www.vermelho.org.br/ diario/2005/1006/1006_historiacongressos.asp. Acesso em: 30 maio 2008). 


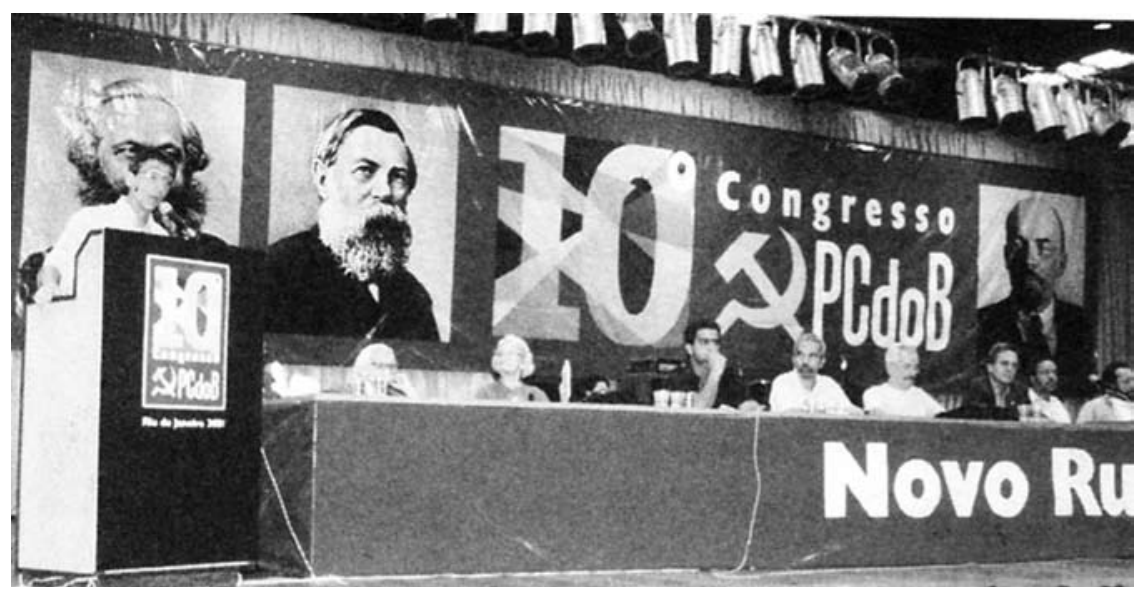

Figura 4 - No X Congresso, realizado em 2001, vêem-se as fotos de Marx, Engels e Lênin e a ausência definitiva de Stalin. (fonte: PCdoB. 10 Congresso do PCdoB. Documentos e resoluções. São Paulo: Anita Garibaldi, 2001. p.334).

Devemos chamar atenção ainda para uma última mudança ocorrida no VIII Congresso, que diz respeito ao abandono da teoria da revolução por etapas, defendida desde a fundação do partido. A partir de 1992, o PCdoB avaliava que a revolução burguesa teria se consolidado e, portanto, a luta deveria ser imediatamente pelo socialismo: "em termos de estratégia política ... somos socialistas e lutamos, desde já, pela vigência do socialismo científico em nossa pátria. É a única e verdadeira solução para os intricados e aflitivos problemas que o país atravessa" (PCdoB, 1992, p.31). Dada a importância da mudança implementada, foi indicado que se criasse uma comissão para elaborar o Programa Socialista do PCdoB. O processo teve desfecho na VIII Conferência Nacional, realizada em agosto de 1995, na qual foi aprovado o novo programa partidário contemplando a estratégia socialista.

É importante frisar que a adoção da perspectiva imediata do socialismo não significou uma mudança na atuação tática do partido. A luta antiimperialista e a proposta de frente ampla dos movimentos populares continuaram no centro de sua prática, vistas agora como momentos necessários para o alcance do socialismo. Segundo o PCdoB, a luta pelo novo regime deveria considerar as particularidades do desenvolvimento dependente do capitalismo no Brasil, sendo necessário imbricar as tarefas de alcançar o socialismo e de solucionar os problemas irresolvidos de caráter democrático e nacional. Assim, a defesa da soberania nacional, a criação das bases para uma economia independente, a reorientação da produção industrial e agrícola e a democratização da nação 
seriam objetivos inseparáveis do socialismo. ${ }^{13} \mathrm{Na}$ prática, o abandono da teoria da revolução por etapas serviu para uma atualização de sua identidade política, deixando de lado um anacrônico legado teórico.

\section{O NOVO INTERNACIONALISMO PROLETÁRIO}

No início da década de 1990, o PCdoB modificou as suas relações com o mundo comunista. Até o final dos anos 80, essa relação havia sido pautada pela crítica ao que ele chamava de revisionismo contemporâneo. Nessa designação estavam a União Soviética, China, Cuba e praticamente todos os partidos comunistas que se encontravam no poder, com os quais o PCdoB rompeu conversações no decorrer de sua história. A ligação do partido se restringia a grupos "marxistas-leninistas" de pouca expressão política. Após o VIII Congresso, vendo-se isolado internacionalmente e enfrentando a crise que se abatia sobre o socialismo, o PCdoB deixou de lado as críticas que fazia ao revisionismo e apontou como tarefa importante a reestruturação da unidade comunista em nível mundial. Não se tratava de criar organismos internacionais ou fazer reuniões deliberativas. Não era o caso, tampouco, de negar a existência de divergências entre os agrupamentos, mas de fazer encontros bilaterais e mesmo reuniões informais para intercambiar opiniões e aproximar os pontos de vista sobre problemas comuns.

A mudança de rumo no campo internacional não se deu sem sobressaltos internos. Alguns militantes viam com estranheza o fato de o partido se reconciliar, por exemplo, com China e Cuba. No primeiro caso, porque as idéias chinesas haviam ocupado espaço importante nas formulações do partido até a segunda metade da década de 1970, quando aconteceu um rompimento abrupto e o partido chinês passou a ser duramente criticado pelo PCdoB. ${ }^{14}$ Já Cuba, depois de uma breve aproximação por parte do PCdoB no início dos anos 60, a partir de 1966 recebera críticas incessantes do partido brasileiro. O momento, porém, era outro, e o PCdoB deixou de arvorar-se em exemplo para o mundo comunista e passou a buscar a convivência política com os partidos comunistas de todo o mundo.

Imbuído desse espírito, em setembro de 1991 o partido já participara de um encontro, em Buenos Aires, organizado pelo Partido Comunista Argentino, cujo objetivo era debater a situação do socialismo no mundo. Para a delegação do $\mathrm{PCdoB}$, a importância da reunião residia na resistência à ofensiva anticomunista que vigorava no período. No mesmo caminho, durante o VIII Congresso, aproveitando-se da presença de partidos estrangeiros convidados, 
realizou uma reunião "informal” sobre a situação internacional. Entre os participantes estava o Partido Comunista Cubano, simbolizando o novo rumo que a política internacional tomaria nos anos seguintes. ${ }^{15}$

Mais representativo ainda da mudança de postura do PCdoB frente aos partidos comunistas foi a viagem realizada por João Amazonas logo após o VIII Congresso, durante a qual esteve em países e com partidos que antes considerava inimigos do socialismo. $\mathrm{O}$ dirigente visitou, entre outros, a Coréia do Norte e a China e se encontrou com os dirigentes do Partido Comunista Português. Na Coréia, a delegação do $\mathrm{PCdoB}$ participou de uma reunião da qual tomaram parte 71 partidos comunistas. Na resolução do encontro, os participantes afirmavam que, apesar de o socialismo ter fracassado em alguns países, o projeto socialista continuava vivo. Da viagem, Amazonas voltou com duas conclusões. A primeira delas dizia respeito à "necessidade de o PCdoB estreitar os contatos internacionais com partidos comunistas de todos os continentes". A segunda apontava que "apesar da onda anticomunista mundial, o que se vê é a proliferação de partidos comunistas em todo o mundo, mostrando que a chamada revolução socialista permanece acesa". ${ }^{16}$

A partir desse momento, o que se pode perceber na política internacional do PCdoB é uma ampliação de seus contatos, agora pautados pelo apoio a todos os partidos comunistas então no poder e a seus respectivos projetos de socialismo. Sobre a China, por exemplo, afirma-se que o país "desenvolve seu próprio caminho socialista - eles consideram estar na fase primária da construção socialista”. Nesta fase, o PCCh "prioriza o desenvolvimento das forças produtivas" e "permite que a economia - predominantemente socialista e controlada pelo Estado popular - interaja e utilize elementos do mercado capitalista interno e externo", o que tem sido motivo de especulações na mídia ocidental. O país, enfim, se situa no campo daqueles "que têm resistido à dominação e ofensiva do imperialismo". A respeito de Cuba, é dito que o país “está saindo do que eles chamam de 'período especial', uma política econômica de guerra, desenvolvida em tempos de paz". Em novembro de 2001, "uma delegação do PCdoB fez uma visita oficial a Cuba. Nessa oportunidade, reforçou seu compromisso com a defesa da revolução cubana e com o apoio e solidariedade ao seu povo". ${ }^{17}$

\section{O DEBATE SOBRE A DEMOCRACIA}

O final da década de 1970 e a primeira metade da seguinte foram marcados pelo longo processo de transição para o regime democrático brasileiro. 
Anistia, mudanças na legislação eleitoral, eleição indireta para presidente e a Constituinte foram alguns temas discutidos nesse período. Não por acaso, ao mesmo tempo ocorreu um debate importante entre as esquerdas sobre a chamada "questão democrática", iniciado por membros do PCB, ainda em 1979, com a publicação de um artigo de Carlos Nelson Coutinho, intitulado "A democracia como valor universal”. Em meados dos anos 80 , a publicação do livro Por que democracia?, de Francisco Weffort, também marcaria a discussão. ${ }^{18}$

O centro da discussão girava em torno da controversa atualidade da idéia de que a democracia era inerentemente "burguesa", "formal" e se contrapunha à "democracia proletária", fruto das transformações decorrentes da revolução social. Vista dessa forma, a democracia "burguesa" era tida pelos comunistas como uma etapa necessária para se chegar à revolução, devendo, assim, ser utilizada taticamente. Essa idéia foi contestada por alguns autores no início da década de 1980, sob o argumento de que a democracia moderna havia se aprimorado e deixado de ser apenas "burguesa", já que abarcara uma série de conquistas sociais a partir das lutas operárias. Nesse sentido, devia-se valorizar o que havia de universal na democracia. No cerne dessa argumentação, colocava-se um questionamento da idéia de ruptura revolucionária, de viés bolchevique, a qual havia guiado a estratégia dos partidos comunistas desde o seu surgimento nos anos 20 .

À discussão sobre a democracia se juntariam ainda as reformas em curso na URSS e a própria crise do socialismo real no final da década de 1980 . No caso do $\mathrm{PCB}$, a conjunção desses debates foi fatal. O partido perdeu a maioria de seus intelectuais, que defendiam as idéias relacionadas ao valor universal da democracia, e mudaria de nome em 1992, passando a se chamar Partido Popular Socialista (PPS). Um pequeno grupo continuou organizado sob a sigla PCB.

O PCdoB só veio a tratar efetivamente da questão no início dos anos 90. Antes, fizera-o apenas tangencialmente porque não se sentia afetado pelas discussões que se davam no âmbito do PCB, partido que sempre criticara como expressão maior do revisionismo no Brasil. Na década de 1980, o PCdoB se aproximava do tema apenas quando publicava em sua imprensa artigos como o de Aranit Cela, presidente da Corte Suprema da Albânia, ou de Luís Fernandes, que ingressaria no Comitê Central do PCdoB em seu VII Congresso. O primeiro artigo procurava demonstrar, a partir do caso albanês, a superioridade da democracia socialista. O segundo argumentava que o marxismo, ao romper com as premissas do liberalismo, conseguira superar a problemática da igualdade, afirmando a questão da liberdade na sociedade mo- 
derna. Entretanto, diferentemente da concepção liberal, no marxismo, “é através da coletividade que o indivíduo se forma e se desenvolve". ${ }^{19}$

No final de 1990, a crise do Leste Europeu, que tinha como um de seus elementos a reivindicação dos povos dos diversos países comunistas pelas liberdades democráticas, juntamente com a difusão da tese do "fim da história”, levou o PCdoB a tratar do tema mais detidamente. Exemplo disso é o número 19 da revista Princípios, de novembro de 1990, o qual dedica vários artigos à discussão sobre a democracia e a liberdade política. Na capa da revista, a chamada sintetiza o posicionamento do partido sobre a questão: "Democracia. Um toque de classe".

$\mathrm{O}$ argumento utilizado pelo $\mathrm{PCdoB}$ é o de que a burguesia sempre procura universalizar suas idéias, retirando delas o caráter "histórico e marca de classe", o que pretendia fazer ao definir como definitiva a democracia de tipo capitalista. Em um dos artigos da revista, o autor afirma que a origem da idéia da democracia como valor universal era antiga e podia ser encontrada nas formulações dos setores reformistas da II Internacional, no eurocomunismo das décadas de 1960 e 1970 e, no Brasil, nas idéias de Weffort e Coutinho. Em sua argumentação, longe de ser universal, a democracia estava inserida na dominação burguesa ("ditadura da burguesia"). Em contraposição a essa democracia, a idéia da ditadura do proletariado continuaria válida. Em outro artigo, o dirigente defendia, contra aqueles que apregoavam a democracia e o pluralismo partidário, o partido leninista baseado nos princípios do centralismo democrático. ${ }^{20}$

O fim do socialismo real, inclusive na Albânia, levou o partido a retomar a discussão sobre a liberdade e a democracia no VIII Congresso. Pouco antes de sua realização, em agosto de 1991, aconteceu um evento que implicou o PCdoB na discussão sobre a democracia. Nesse mês, houve uma tentativa de golpe de Estado na União Soviética contra o governo de Gorbatchev, liderado por setores do exército e do partido comunista, descontentes com as reformas em andamento. Em artigo publicado no jornal Folha de S. Paulo, o presidente do partido, João Amazonas, chamou de "acontecimento alvissareiro" o que se passava na União Soviética. Na análise de Amazonas, o golpe era uma reação à política revisionista de Gorbatchev, que procurava reintroduzir o capitalismo no país. As afirmações do dirigente causaram divergências no interior do partido, as quais apareceram nos debates preparatórios para o congresso. Vários militantes criticaram a posição de Amazonas diante da tentativa de golpe contra o governo russo. ${ }^{21}$

A problemática da liberdade também apareceu na preparação do con- 
gresso, nas discussões de outros temas importantes. Por exemplo, pela primeira vez na história do PCdoB, dirigentes criticaram a experiência do partido único que vigorou na Uniião Soviética, defendendo que as divergências no socialismo deveriam ser expressas abertamente. Aldo Arantes, mesmo considerando as diferenças entre a democracia socialista e a burguesa, defendia que os avanços desta última deveriam ser aproveitados no socialismo. Mais um tema que trouxe consigo a temática da liberdade foi o do realismo socialista, experiência que também recebeu críticas de parte da militância. ${ }^{22}$

Essas afirmações poderiam indicar uma mudança da postura do PCdoB em relação à questão das liberdades democráticas, no entanto, o partido reafirmou o princípio de que a democracia socialista, a ditadura do proletariado, era superior à democracia burguesa. Dessa forma, ao mesmo tempo em que apontava que a luta pela ampliação da democracia era fator primordial de sua tática política, ela seria uma etapa necessária para a edificação da futura sociedade socialista. Diante das críticas que o socialismo recebia e do destaque que o debate sobre a democracia "como valor universal" ganhava no país, o partido dedicou um informe especial ao tema durante a realização do VIII Congresso. A intervenção foi elaborada por Luís Fernandes, membro do Comitê Central. Em suas conclusões, está sintetizado o posicionamento partidário frente à questão: "a crise do socialismo e as transformações ocorridas no mundo capitalista não invalidam os conceitos marxistas de democracia e ditadura do proletariado". ${ }^{23}$

\section{Conclusões}

O PCdoB saiu fortalecido do VIII Congresso. Em contraste com outras agremiações congêneres existentes no mundo, o grupo logrou superar a crise do socialismo e ampliar a sua inserção social no país. É certo que o crescimento relativo do partido na última década não pode ser creditado unicamente aos desdobramentos desse congresso. Pode-se lembrar, por exemplo, de suas sucessivas coligações eleitorais com o PT, maior partido da esquerda brasileira, que certamente ajudaram no crescimento e maior inserção social do PCdoB. No entanto, é possível afirmar que as modificações introduzidas a partir de 1992 certamente colaboraram para que trilhasse o caminho que singulariza hoje a sua atuação, marcada por uma paulatina institucionalização de suas demandas e atuação política.

Entre as modificações mais evidentes na política partidária, as quais estão relacionadas à crise do socialismo, destacam-se: o abandono da teoria da 
revolução por etapas, com adoção de uma perspectiva socialista e a aceitação da pluralidade de idéias e do caminho institucional; a crítica, mesmo com nuanças, ao legado stalinista, com a incorporação de regras de funcionamento interno mais democráticas; o debate sobre a democracia, que até o início da década de 1990 não havia sido feito pelo partido; a abertura de sua política de relações internacionais, com a aproximação de países que até então eram fortemente criticados, como China e Cuba, bem como o reatamento de conversações com diversos partidos comunistas antes chamados de revisionistas.

Além das mudanças aqui citadas, vale chamar atenção para um aspecto menos evidente do debate, mas certamente importante para a reflexão feita neste artigo. Observadas em conjunto, as transformações implementadas pelo partido dizem respeito, essencialmente, a um acerto no compasso de sua relação com a tradição comunista, oriunda de interpretações de variados autores, mas tendo como núcleo Marx, Lênin e Stalin. O que se percebe no final dos debates do VIII Congresso, e nos anos subseqüentes da história partidária, é que o balanço crítico feito em relação a tal tradição, ainda que discreto, tornou possível ao PCdoB rever uma série de aspectos de suas propostas e práticas políticas, sem que isso significasse o abandono do marxismo-leninismo e da perspectiva socialista de sociedade.

Nesse percurso, o que resultou do debate suscitado pela crise do comunismo para o PCdoB foi, paradoxalmente, a reafirmação dos princípios do marxismo-leninismo, particularmente a defesa da superioridade da ditadura do proletariado e do socialismo em relação ao capitalismo, modificando-se, no sentido da adequação institucional, aspectos de sua atuação política. Talvez essa particularidade do $\mathrm{PCdoB}$, a discussão de aspectos secundários e não da essência de sua identidade, explique o fato de ele não ter sucumbido à crise que atingiu diversos partidos comunistas no mundo. Tais características do debate podem explicar ainda a surpreendente coesão de sua militância em torno das propostas e princípios partidários, o que possibilitou ao $\mathrm{PCdoB}$ experimentar um importante crescimento numérico e político nos últimos anos.

Os resultados práticos da superação da crise pelo $\mathrm{PCdoB}$ podem ser verificados em seu crescimento desde meados da década de 1990. Já nas eleições municipais de 1992, mesmo diante da grande campanha anticomunista feita pelos meios de comunicação, o partido elegeu 53 vereadores. Na eleição de 1994, a sua representação na Câmara Federal passou de 5 para 10 deputados e, ainda em 1993, conseguiu o seu registro definitivo junto ao TSE. Nos anos seguintes, apoiou as coligações que sustentaram a candidatura de Luís Inácio 
Lula da Silva nas derrotas de 1989, 1994 e 1998. Em 2002, chegou ao poder junto com os petistas na eleição presidencial e ocupou cargos no governo federal.

Além do fortalecimento institucional, o PCdoB passou a ter significativa importância em sua atuação em movimentos sociais organizados. Foi praticamente hegemônico no decorrer da década de 1990 no Movimento Estudantil, particularmente entre as lideranças da União Nacional dos Estudantes. No setor sindical, atuou desde meados dos anos 80 na CUT, através da Corrente Sindical Classista. Em 2007, juntamente com outras forças políticas, fundou uma nova central sindical, a Central dos Trabalhadores e Trabalhadoras do Brasil (CTB).

\section{NOTAS}

${ }^{1}$ SALES, Jean Rodrigues. O PCdoB e o movimento comunista internacional nos anos 60. História, questões e debates, Curitiba: Ed. UFPR, n.35, p.275-303, 2001; O PCdoB conta a sua história: tradição, memória e identidade política. Diálogos, Maringá: Ed. UEM, v.6, p.155-171, 2002; O PCdoB nos anos 60: estruturação orgânica e atuação política. Cadernos AEL / Tempo de ditadura: do golpe aos anos 70, Campinas (SP): Ed. IFCH, v.8, n.14-15, p.13-49, 2001; Partido Comunista do Brasil (PCdoB): definições ideológicas e trajetória política. In: REIS FILHO, D. A.; RIDENTI, M. (Org.). História do marxismo no Brasil. v.VI. Campinas (SP): Ed. Unicamp, 2006. p.63-103; Da luta armada ao governo Lula: a história do Partido Comunista do Brasil (PCdoB). In: FERREIRA, J.; REIS FILHO, D. A. As esquerdas no Brasil. v.3. Rio de Janeiro: Civilização Brasileira, 2007. p.163-182.

${ }^{2}$ Até pouco tempo atrás seria praticamente impossível a escrita de um artigo de história versando sobre um período recente, vivido pelo próprio autor. Felizmente, hoje, os historiadores que estudam o presente já encontram subsídios teóricos que ajudem em seu caminho. Para o estudo da história do tempo presente, assim como de qualquer período, faz-se necessário o amparo teórico e o diálogo com o campo de estudo com o qual se está tratando. Neste caso, acredito que os aportes do Instituto de História do Tempo Presente, da França, ajudam a enfrentar as questões colocadas. O Brasil também tem produzido trabalhos na área, como atesta a produção dos pesquisadores do CPDOC e de outros grupos de pesquisa em atuação no país. Cf. CHAUVEAU, A.; TÉTARD, P. (Org.). Questões para a história do presente. Bauru: Edusc, 1999; RÉMOND, R. Por uma história política. 2.ed. Rio de Janeiro: FGV, 2003; FERREIRA, M. de M.; AMADO, J. (Org.). Usos \& abusos da história oral. 8.ed. Rio de Janeiro: FGV, 2006; PORTO JR., G. (Org.). História do tempo presente. Bauru (SP): Edusc, 2007.

${ }^{3}$ Sobre a crise do socialismo real, ver, entre outros: ELEY, G. Forjando a democracia: a história da esquerda na Europa, 1850-2000. Trad. Paulo Cézar Castanheira. São Paulo: Perseu Abramo, 2005; REIS FILHO, D. A. Uma revolução perdida: a história do socialismo 
soviético. São Paulo: Perseu Abramo, 1997; REIS FILHO, D. A. Crise e desagregação do socialismo. In: REIS FILHO, D. A.; FERREIRA, J.; ZENHA, C. (Org.). O século XX: o tempo das dúvidas. 3.ed. Rio de Janeiro: Civilização Brasileira, 2005. p.161-183; GORENDER, J. Origens e fracassos da perestroika. São Paulo: Atual, 1992.

${ }^{4} \mathrm{PCdoB}$. A política revolucionária do PCdoB. Informes ao $7^{\circ}$ Congresso realizado em maio de 1988. São Paulo: Anita Garibaldi, 1989. p.43.

${ }^{5}$ Cf. CARVALHO, José Reinaldo. Resgate da coerência contra o ecletismo. Princípios. São Paulo: Anita Garibaldi, n.18, p.28-34, 1990; A classe operária, 2 a 15 mar. 1990, p.1. Ver ainda, nessa edição, um suplemento especial sobre a Albânia.

6 "Trofim Denissovitch Lyssenko, nascido na Ucrânia, era um obscuro criador de plantas que propôs teses mirabolantes a respeito de colheitas e produtividade. Tais idéias eram desenvolvidas em contraposição total às conclusões dos estudos do Ocidente. De 1927 a 1948, pelas mãos de Stalin, Lyssenko teve ascensão vertiginosa no poder soviético. A genética ocidental foi denunciada na União Soviética e seus praticantes perseguidos. A cartilha que valia era a de Lyssenko. Por conta desta mistura inflamável entre ciência e interesses políticos a pesquisa genética soviética entrou em crise. O lyssenkismo com seu padrão de apadrinhamento e como proposta de metodologia científica fracassou radicalmente". Disponível em: pt.wikipedia.org/wiki/Lyssenko. Acesso em 15 jan. 2008.

7 “A luta pelo socialismo científico". Tese apresentada ao $8^{\circ}$ Congresso do PCdoB, mimeo, p.13. A respeito do tema, ver ainda SILVA, Antônio Ozai da. Os comunistas diante do muro: o marxismo-leninismo entre a negação e a afirmação da tradição stalinista. Diálogos, Maringá: Ed. UEM, v.3, n.3, p.263-290, 1999; RIDENTI, Marcelo. O impacto da crise do socialismo no Partido Comunista do Brasil, 1988-1992. Perspectivas, São Paulo: Ed. FCLA, n.17-18, p.75-94, 1994-1995.

${ }^{8}$ Cf. CARVALHO, Pedro. "É preciso evitar a repetição dos erros". Tribuna de Debates, n.1, p.4; A classe operária, 2 ago. 1991; SOARES, Angela. "História e verdade”. Tribuna de Debates, n.4, p.8; A classe operária, 16 set. 1991.

${ }^{9}$ OLIVEIRA FILHO, Moacyr de. "Sonhar também é preciso". Tribuna de Debates, n.8, p.8; A classe operária, 11 a 24 nov. 1991. Ver ainda: MARTINS, Antonio. "O PCdoB na encruzilhada histórica”. Tribuna de Debates, n.2, p.6; A classe operária, 19 ago. 1991.

${ }^{10}$ FREIRE JR., Olival. “A Albânia é um caso encerrado para o PCdoB?”. Tribuna de Debates, n.2, p.4; A classe operária, 19 ago. 1991; BRABO, Antonio Carlos. "A defesa cega de princípios". Tribuna de Debates, n.3, p.4; A classe operária, 2 set. 1991; CARVALHO, Pedro. "É preciso evitar a repetição de erros". Tribuna de Debates, n.1, p.4; A classe operária, 2 ago. 1991.

${ }^{11}$ Cf. PCdoB. O socialismo vive. Documentos e resoluções do $8^{\circ}$ Congresso do Partido Comunista do Brasil - PCdoB. 2.ed. São Paulo: Anita Garibaldi, 1992. p.46-49.

${ }^{12}$ Cf. SANTOS, Nilo Walter dos. "Socialismo: regime superior". Tribuna de Debates, n.5, p.15; A classe operária, 3 out. 1991; MACHADO, Elizeu R. "Socialismo é científico!". Tribuna de Debates, n.10, p.30; A classe operária, 13 dez. 1991. 
${ }^{13}$ SILVA, Antonio Ozaí da. Os partidos, tendências e organizações marxistas no Brasil (1987-1994): permanências e descontinuidades. Dissertação (Mestrado em Ciências Sociais) - PUC/SP. São Paulo, 1998. p.76-77. Ver também a intervenção no VIII Congresso de Rogério Lustosa: "Socialismo: tarefa que se impõe". In: PCdoB. O socialismo vive, 1992. p.63-69.

${ }^{14}$ Sobre o rompimento com a China, ver "Breve histórico das divergências com o PC da China". A classe operária, dez. 1978. Vale frisar que durante os eventos da Praça da Paz Celestial, em 1989, o PCdoB ainda criticou duramente os chineses e afirmou que o país não era comunista. Cf. "Novos crimes do revisionismo chinês". A classe operária, 15-28 jun. 1989; 29 jun.-12 jul. 1989.

15 "Esquerda latina busca unidade". A classe operária, 14-27 out. 1991, p.10; "Reunião informal de 24 partidos comunistas". A classe operária, 24 fev.-8 mar. 1992, p.12.

16 "Declaração de Pyonyang". A classe operária, 25 maio 1992, p.7; "Amazonas vê socialismo vivo no mundo". A classe operária, 25 maio 1992, p.7.

${ }^{17}$ Informações sobre a China e Cuba disponíveis em: www.vermelho.org.br/pcdob/faq. asp\#18; acesso em 15 jan. 2008.

${ }^{18}$ Cf. COUTINHO, Carlos Nelson. A democracia como valor universal. Encontros com a civilização brasileira, São Paulo: Brasiliense, v.1, n.9, p.33-47, 1979; WEFFORT, Francisco. Por que democracia? São Paulo: Brasiliense, 1984. Não é objetivo deste artigo aprofundar a discussão sobre o debate em torno da questão democrática no período. O mais importante é verificar como o PCdoB se posicionou a respeito do tema e as conseqüências para a política do partido. Além dos livros de Coutinho e Weffort, aqui citados, para uma idéia das discussões entre intelectuais no período em que se desenvolvia o debate, ver: GARCIA, Marco Aurélio (Org.). As esquerdas e a democracia. Rio de Janeiro: Paz e Terra, 1986. Uma boa resenha a respeito do debate sobre a questão democrática dentro do PCB, inclusive com a indicação de ampla bibliografia no final, ver: ROMANO, Clayton Cardoso. Da abertura à transição: o PCB e a cultura política democrática da esquerda brasileira. Dissertação (Mestrado em História) - Unesp. Franca, 2001; e SILVA, Fabrício Pereira da. Utopia dividida. Crise e extinção do PCB (1979-1992). Dissertação (Mestrado em História) - UFRJ. Rio de Janeiro, 2005.

${ }^{19}$ CELA, Aranit. A democracia e a ditadura do proletariado na Albânia socialista. Princípios, São Paulo: Anita Garibaldi, n.13, p.13-19, 1986; FERNANDES, Luís. O marxismo e o impasse entre igualdade e liberdade no pensamento liberal. Ibidem, p.36.

${ }^{20}$ Cf. RUY, José Carlos. Qual democracia? Qual ditadura? Princípios, São Paulo: Anita Garibaldi, n.19, nov. 1990, p.14; LUSTOSA, Rogério. O canto da sereia de um partido para todos. Ibidem, p.22-29. Ainda sobre a questão da historicidade da idéia de liberdade, ver GUASCO, Madalena. Liberdade: dois passos à frente — dez atrás. Ibidem, p.30-39.

${ }^{21}$ AMAZONAS, João. Acontecimento alvissareiro. Folha de S. Paulo, 20 ago. 1991. Reações ao artigo do dirigente, ver, por exemplo, GRANJA, Marcelino. "Por que o partido foi simpático ao golpe de estado na URSS?”. Tribuna de Debates, n.4, p.2. A classe operária, 19 set. 
1991; e MEDEIROS, Gerson. "Stalinismo, burocracia e contra-revolução". Tribuna de Debates, n.10, p.42; A classe operária, 13 dez. 1991.

${ }^{22}$ JOFFILY, Bernardo. "O partido único não deu certo". Tribuna de Debates, n.2, p.11; A classe operária, 19 ago. 1991; ARANTES, Aldo. "Democracia burguesa e democracia proletária”. Tribuna de Debates, n.8, p.15; A classe operária, 11-24 nov. 1991; ALVES, José Francisco. "Realismo socialista, experiência equivocada". Tribuna de Debates, n.5, p.11; A classe operária, 3 out. 1991.

${ }^{23}$ FERNANDES, Luís. A atualidade dos conceitos de democracia e ditadura do proletariado. In: PCdoB, O socialismo vive, 1992, p.80.

Artigo recebido em junho de 2008. Aprovado em setembro de 2008. 